\title{
The physico-chemical diversity of pit lakes of the Muskau Arch (Western Poland) in the context of their evolution and genesis
}

\author{
Andrzej Pukacz ${ }^{1 *}$, Małgorzata Oszkinis-Golon ${ }^{2}$, Marcin Frankowski $^{3}$ \\ ${ }^{1}$ Polish-German Research Institute at Collegium Polonicum, Adam Mickiewicz University, Kościuszki 1, 69-100 Słubice, Poland, e-mail: \\ pukacz@europa-uni.de ( ${ }^{*}$ corresponding author) \\ ${ }^{2}$ Faculty of Biological Sciences, University of Zielona Góra, Prof. Z. Szafrana 1, 65-516 Zielona Góra, Poland, e-mail: gosiaoszkinis@wp.eu \\ ${ }^{3}$ Department of Water and Soil Analysis, Faculty of Chemistry, Adam Mickiewicz University in Poznań, Poland, Umultowska 89b, PL-61- \\ 614 Poznań, Poland, e-mail: marcin.frankowski@amu.edu.pl
}

\begin{abstract}
In the vegetation seasons 2016-2017, a survey of 30 pit lakes localized in the eastern part of the Muskau Arch (Western Poland) was carried out. The aim of the study was to characterize the habitat conditions of the selected lakes, based on the physico-chemical water characteristics. We hypothesized that the age and genesis of pit lakes are the main factors responsible for their hydro-chemical diversity. Therefore, in each of the lakes 27 physico-chemical parameters and chlorophyll a were measured in the water surface, in the peak of the vegetation season (July-August). Additionally, they were described in terms of genesis, origin and age. The results showed that the investigated lakes display a high diversity of habitat conditions reflected in varied physico-chemical water properties (significant laketo-lake differences). The parameters mostly responsible for the differences were: Secchi depth (transparency), $\mathrm{pH}, \mathrm{EC}, \mathrm{colour}, \mathrm{hardness,}$ TP, TN, TC, $\mathrm{Ca}^{2+}, \mathrm{Mg}^{2+}, \mathrm{Fe}, \mathrm{Al}, \mathrm{Mn}, \mathrm{S}$ and $\mathrm{Chl}$ a. The comparison of the type of excavated aggregate showed significant differences for four parameters only. Much greater differences were found for the genesis of lakes (mining method) - 15 of the 28 analysed parameters significantly differentiated the lakes. Further analysis showed that half of the studied parameters were significantly correlated with the age of the pit lakes. Our results suggest that in addition to natural changes, secondary human-caused transformations (mostly neutralization and fertilization of the water) were among the key factors responsible for the differentiation of the lakes.
\end{abstract}

Key words: pit lakes, Muskau Arch, Łuk Mużakowa, water chemistry, neutralization

\section{Introduction}

Apart from natural water ecosystems, pit lakes have been present in the landscape for centuries. Due to their anthropogenic character, these water bodies are very diverse, not only in terms of morphometric structure but also in terms of water chemistry (Koźma 2016). Depending on the kind of ore that was extracted there in the past, pit lakes may be created in former brown coal, clay, sand and gravel mines, building stone quarries and peat bogs (Sienkiewicz and Gąsiorowski 2016).

Lakes formed in brown coal mines are the most common in Europe, also in Poland. They are mainly located near large deposits, e.g., in Konin, Bełchatów, Turów and the region of Silesia (Kasztelewicz 2012). They are usually highly acidic ( $\mathrm{pH}$ of even 2.0) and mineralized (Moser and Weisse 2011; Koschorreck and Tittel 2002). This is mostly the effect of washing out from the drainage area and oxidation of pyrite $\left(\mathrm{FeS}_{2}\right)$ and other sul- phur compounds. In addition, the waters often contain high heavy metal concentrations (Blanchette and Lund 2016), which is also typical and well described for other post-mining lakes (e.g., Rzymski et al. 2017; SameckaCymerman and Kempers 2004). Consequently, in such a noxious, toxic environment it is very difficult for organisms to develop and maintain themselves (Jędrczak et al. 1998; Nixdorf et al. 1998).

Depending on the material in the lake basin and the drainage area, the chemical composition of pit lake waters may be extremely diverse (Jędrczak 1992; Sienkiewicz and Gąsiorowski 2016). One of the effects of this chemical differentiation is a very diverse colour of water found in particular lakes (Blanchette and Lund 2016). The chemical composition also depends on the extraction of other kinds of ore apart from coal (Boehrer 2013). The method of extraction (underground or open-cut) is very important too, as it determines the morphometric structure of the lakes, and hence their future habitat di- 
versification. Due to its particular morphometric structure (low surface to depth ratio) and the inflow of highly mineralized water from the drainage area, in some of the lakes the rare phenomenon of meromixis can be observed (Schultze and Boehrer 2008).

Besides their origin, the age of the lakes is another important element that may influence their diversity and evolution. This depends not only on the time of mine closure, but also on the speed of flooding the pit (Matejczuk 1986). As a result, the speed of biocenosis succession processes may differ, and consequently cause the diversification of the lakes.

Under the influence of hydrochemical changes connected i.a., with the processes of secondary succession and the management of the drainage area, over time the lakes tend to become increasingly similar to natural ones (Sienkiewicz and Gąsiorowski 2016). Just as in the case of natural water ecosystems, these changes are very slow (Schultze et al. 2013). Unfortunately, as a result of secondary management, degradation processes and accelerated decline of lakes occur in many places. Liming and fertilization (e.g., with domestic wastewater) in order to stock the lakes with fish (mostly with carp), despite being illegal, is quite common in many places (Schultze et al. 2010).

The lakes in the Muskau Arch (in Polish: Łuk Mużakowa) in the Polish-German borderland are an example of well-preserved pit lakes. These lakes were created at the turn of the 20th century (Matejczuk 1989), but their habitat and biocenotic conditions are still not well known. This is mostly because they are located in a heavily forested, hilly area, which makes their access difficult.

Most of these lakes were formed as a result of brown coal mining, but the mining industry in that area also involved other minerals, such as clay and gravel (Najbar and Jędrczak 1998; Koźma and Kupetz 2008). Some of the lakes formed as soil layers settled over closed underground mining pits, which led to the formation of sink holes. Other lakes were made in pits of open-cut brown coal and ceramic clay mines. Studies carried out in the 1980 s and 90s point to the huge diversification of water chemistry in the lakes (Matejczuk 1989; Najbar and Jęrczak 1998), pH, redox, sulfates and iron contents. In some lakes, visible changes in trophy have occurred (Sienkiewicz and Gąsiorowski 2016). This is reflected i.a., in the great variety of water colour, thus the area is often referred to as the "colourful lake district".

The above-mentioned examples of investigation performed in the area of the Muskau Arch and other locations (e.g., Blanchette and Lund 2016; Kupetz 1997) point to the unique character of pit lakes. For many years, the newly formed lakes were not used by the local community, mainly due to their very high acidity and mineralization. Thus, many of them have not yet been transformed by human activity and have preserved their original character. However, over the years some of them began to be transformed for the needs of fish stocking. These treatments were preceded by the process of liming and fertilization with domestic waste water, which had a great impact on the transformation (e.g., biological succession) and degradation of many of these lakes. Therefore, research carried out in these ecosystems provides a special opportunity to study a number of rare geochemical processes as well as other phenomena and transformations over time. So as to be able to interpret and understand them properly, it seems necessary to explore the habitat variety well, especially as many lakes in the Muskau Arch have never been studied.

The aim of this study was to characterize the habitat conditions of 30selected lakes of the Muskau Arch based on the analysis of 27 physico-chemical parameters of water and, additionally chlorophyll- $a$ concentration. We hypothesized that the main factors responsible for the diversification of physico-chemical water parameters are the age and origin of the lakes.

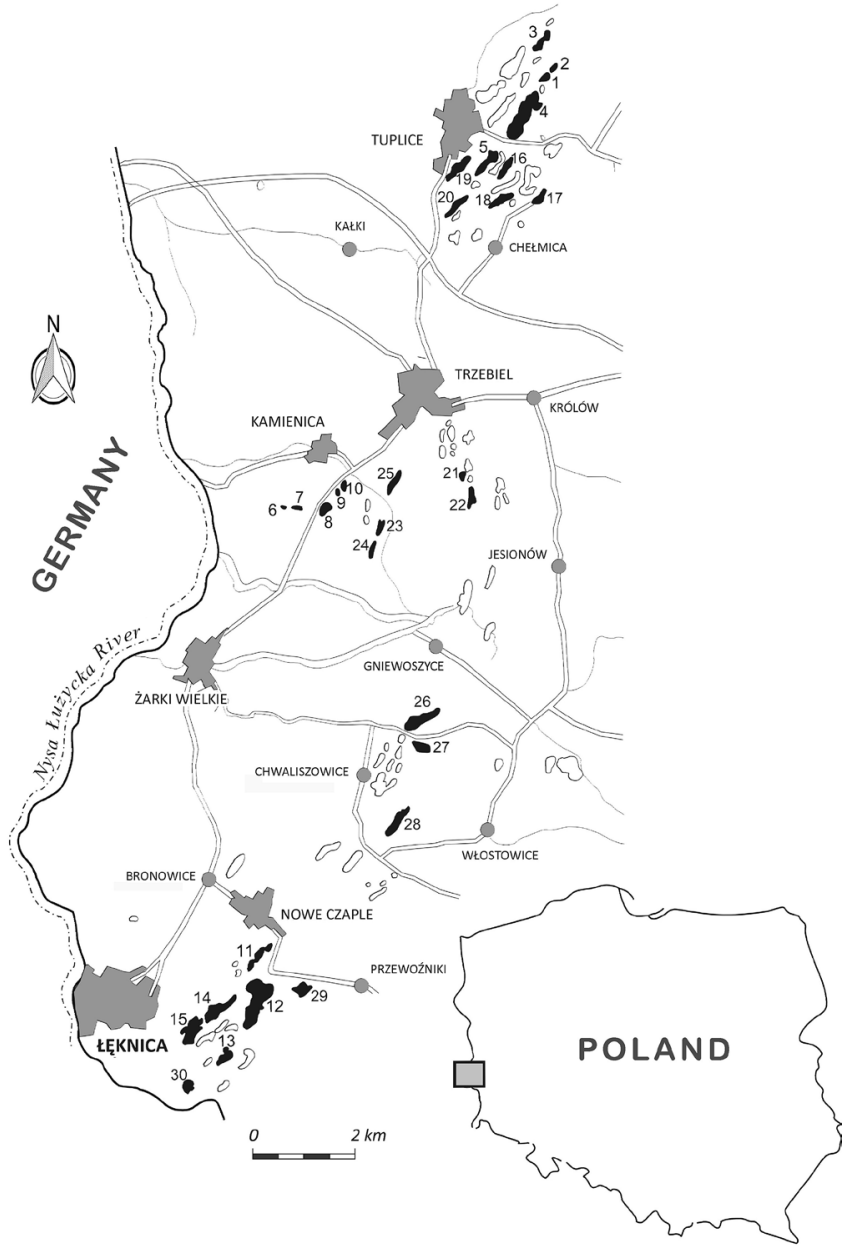

Fig. 1. The locality and spatial distribution of the investigated lakes (marked in black and numbered) 


\section{Study area}

Thirty pit lakes located within the Muskau Arch (Western Poland, Fig. 1) were studied in the vegetation seasons of 2016 and 2017. This area is one of the largest and best preserved end moraines in Europe and is protected as part of the Muskau Arch Landscape Park. It is a horseshoe-shaped arch with ends facing north, stretching from the towns of Tuplice, Trzebiel and Lęknica in Poland to Weisswasser and Dobern in Germany. The valley of the Lusatian Neisse river, which runs along the border between Poland and Germany, cuts across the area in the middle. One of the secondary effects of a pressing continental glacier was the disturbance of geological strata, for example pushing upwards the lower deposits of brown coal. In such places, brown coal was originally extracted, and later pit lakes developed (Koźma and Kupetz 2008).

With regard to spatial distribution in the Muskau Arch, we can identify three main clusters of lakes located at the towns of Tuplice, Trzebiel and Lęknica.
This spatial diversification results from the geological structure of the Muskau Arch and the distribution of coal deposits (Koźma and Kupetz 2008). Ten lakes were selected for the study from each area (five in each year).

The origin and age of the lakes (Table 1) were determined on the basis of historical data analysis (i.a., Dawczyk and Maciantowicz 2014 and literature quoted therein) as well as geological maps and unpublished sources of the Polish Geological Institute in Wrocław (Koźma 2018, unpubl. data). Regarding their origin, three groups of lakes were identified: sink hole, open-cut and sink hole/open-cut. Sink hole lakes were formed as a result of underground brown coal extraction. Open-cut lakes were formed in the places of open pits, mostly after the extraction of clay. Sink hole/opencut lakes were formed as a result of underground brown coal extraction and open-cut clay extraction.

Due to their varied origin and different source data, the age of each lake was counted from the date of mine closure (Table 1). The oldest mining lakes are located in the northern part of the area (near Tuplice). Their age is

Table 1. Basic characteristics of the investigated pit lakes

\begin{tabular}{|c|c|c|c|c|c|c|c|c|}
\hline Lake No. & Origin & Genesis & Age [years] & Area [ha] & Max. depth [m] & $\mathrm{pH}$ & Conductivity $\left[\mu \mathrm{S} \mathrm{cm}^{-1}\right]$ & Secchi depth [m] \\
\hline 1 & $\mathrm{C}$ & $S$ & 92 & 0.84 & 1.8 & 6.9 & 206 & 0.20 \\
\hline 2 & C & $S$ & 92 & 0.11 & 3.6 & 7.2 & 179 & 1.20 \\
\hline 3 & C & $S$ & 92 & 2.62 & 6.0 & 6.9 & 274 & 2.20 \\
\hline 4 & C & $S$ & 145 & 11.79 & 2.8 & 7.0 & 349 & 0.50 \\
\hline 5 & $\mathrm{C}, \mathrm{L}$ & S-O & 146 & 3.68 & 3.5 & 6.8 & 323 & 1.10 \\
\hline 6 & $\mathrm{C}$ & $S$ & 123 & 0.64 & 6.0 & 7.4 & 116 & 1.30 \\
\hline 7 & $\mathrm{C}$ & $S$ & 123 & 0.67 & 8.9 & 7.4 & 100 & 2.50 \\
\hline 8 & C & $S$ & 113 & 1.89 & 10.2 & 7.5 & 178 & 1.60 \\
\hline 9 & C & $S$ & 90 & 1.00 & 5.0 & 7.2 & 93 & 1.20 \\
\hline 10 & C & $S$ & 90 & 1.27 & 4.5 & 7.4 & 115 & 1.30 \\
\hline 11 & $\mathrm{C}, \mathrm{L}$ & $\mathrm{S}-\mathrm{O}$ & 61 & 3.67 & 11.6 & 3.6 & 439 & 4.10 \\
\hline 12 & C & 0 & 49 & 18.45 & 22.4 & 2.8 & 1036 & 4.00 \\
\hline 13 & $C$ & 0 & 44 & 0.62 & 3.4 & 2.8 & 2400 & 2.20 \\
\hline 14 & $\mathrm{C}, \mathrm{L}$ & S-O & 42 & 6.09 & 9.4 & 4.0 & 585 & 3.80 \\
\hline 15 & C, L & S-O & 64 & 6.49 & 15.4 & 3.6 & 834 & 5.40 \\
\hline 16 & $\mathrm{C}$ & $S$ & 145 & 8.90 & 5.8 & 6.0 & 270 & 2.20 \\
\hline 17 & L & 0 & 90 & 2.28 & 9.0 & 7.0 & 336 & 1.90 \\
\hline 18 & L & 0 & 79 & 2.16 & 7.4 & 6.9 & 239 & 1.90 \\
\hline 19 & $C$ & $S$ & 79 & 3.44 & 8.2 & 5.3 & 377 & 1.50 \\
\hline 20 & $\mathrm{C}, \mathrm{L}$ & $\mathrm{S}-\mathrm{O}$ & 117 & 2.31 & 4.4 & 7.1 & 300 & 1.20 \\
\hline 21 & $\mathrm{C}, \mathrm{L}$ & S-O & 74 & 0.72 & 8.7 & 3.0 & 765 & 4.15 \\
\hline 22 & C & $S$ & 74 & 1.71 & 12.0 & 2.8 & 1153 & 4.80 \\
\hline 23 & C & $S$ & 90 & 1.27 & 9.1 & 6.7 & 155 & 2.00 \\
\hline 24 & C & $S$ & 90 & 0.98 & 8.4 & 6.4 & 110 & 1.85 \\
\hline 25 & $C$ & $S$ & 90 & 2.34 & 12.2 & 6.7 & 292 & 1.40 \\
\hline 26 & L & 0 & 87 & 5.98 & 15.7 & 2.9 & 973 & 2.00 \\
\hline 27 & $\mathrm{~L}$ & 0 & 35 & 2.32 & 9.0 & 3.4 & 333 & 2.70 \\
\hline 28 & $\mathrm{C}, \mathrm{L}$ & 0 & 72 & 5.20 & 11.4 & 3.5 & 352 & 6.00 \\
\hline 29 & C, L & 0 & 49 & 2.99 & 11.0 & 3.7 & 295 & 7.40 \\
\hline 30 & $C$ & 0 & 49 & 2.41 & 8.2 & 2.9 & 1720 & 3.30 \\
\hline
\end{tabular}

Abbreviations: C - coal, L- lime, S - sink hole, O - open-cut, S-O - sink hole/open-cut. 
146 and 145 years (lake no. 5 and 4 and 16, respectively). The youngest lakes are located in the most southerly area (mainly near Łęknica). The youngest one, aged 35 years, is lake no. 27.

Before the survey, a Lowrance Mark 5x Pro fish finder was used in each lake to determine the maximum depth and any potential bottom anomalies. The surface area of each lake was determined using maps and satellite images as well as Geoportal tools. The depth of the lakes ranged from 1.8 to $22.4 \mathrm{~m}$, and the surface area from 0.11 to 18.45 ha (Table 1 ). Lake no. 12 , located near Łęknica, is the deepest and the largest. The shallowest one is lake no. 1 , and the smallest lake no. 2 , both located near Tuplice. The morphological and age diversification of the studied lakes was largely reflected in the basic physico-chemical properties of water (Table 1).

\section{Methods}

In each lake, basic physico-chemical analyses were performed during the vegetation season peak (JulyAugust) in the surface waters of the central basin. Electrolytic conductivity (EC), redox and $\mathrm{pH}$ were measured directly in the field, in the deepest, vegetation-free part of each lake, using an Elmetron CX-701 meter, and transparency with a Secchi disk (SD). Oxygen concentration and temperature were measured using an Elmetron CX-401 meter.

All the measurements and water sampling for the laboratory analyses were performed in the central basin at a depth of $0.5 \mathrm{~m}$. Water samples (one sample per lake) for further laboratory analyses were collected in one-litre plastic bottles and kept in a portable refrigerator. After the alkalinity analysis (performed in a laboratory within 6 hours after the sampling), the samples were kept in a refrigerator $\left(\right.$ at $\left.4^{\circ} \mathrm{C}\right)$ until the remaining chemical analyses were performed at the Department of Water and Soil Analysis, Faculty of Chemistry, Adam Mickiewicz University in Poznań. All the laboratory measurements were repeated for at least 3 subsamples.

Additionally, a one litre sample from the surface water was taken to determine chlorophyll- $a$ concentration $(\mathrm{Chl}-a)$. The water was filtered immediately after the field surveys through Whatman GF/C filters, which were kept frozen. After thawing and acetone extraction, the samples were processed according to the method proposed by Golterman (1969).

Concentrations of total carbon (TC), inorganic carbon (IC) and total organic carbon (TOC) as well as total nitrogen $(\mathrm{TN})$, were determined in the filtered samples $(0.45 \mu \mathrm{m}$ pore size filter $)$ by high-temperature combustion (HTC) using a Shimadzu TOC-L Total Organic Carbon analyzer (Shimadzu, Japan). For TN determination the analyzer was equipped with a TNM-L
TN unit (Shimadzu, Japan).The concentrations of $\mathrm{Cl}^{-}$, $\mathrm{SO}_{4}^{2-}, \mathrm{NO}^{2-}, \mathrm{NO}^{3-}$ and $\mathrm{NH}_{4}^{+}$ions were determined by the ion chromatography method with a conductivity detector (Shimadzu, Japan) using Thermo AS22 with AG22 columns (e.g. Baird and Bridgewater 2017). Organic nitrogen $\left(\mathrm{N}_{\text {org. }}\right.$ ) was determined by the Kjeldahl method.

Alkalinity was determined by the titration method with an indicator, and colour - by the visual method against the platinum scale. Total water hardness was determined by the versenate method. In order to determine $\mathrm{Ca}^{2+}$ and $\mathrm{Mg}^{2+}$ ion concentration, a Metrohm ion chromatograph, 881 Compact IC Pro model (Metrohm, Switzerland) was applied, using columns Metrosep C 4 Guard (the guard column) and Metrosep C4 150 (the separating column). The $\mathrm{Fe}^{3+}$ concentration was determined by the spectrophotometric method.

An inductively coupled plasma optical emission spectrometer (ICP-OES) ICPE-9820 (Shimadzu, Japan) with a mini-torch was used for the qualitative and quantitative detection of: $\mathrm{Na}, \mathrm{K}, \mathrm{Fe}, \mathrm{Al}, \mathrm{Mn}, \mathrm{TP}, \mathrm{S}$. Prior to the analysis, the Sigma-Aldrich (USA) periodic table mix 1 for ICP containing $10 \mathrm{mg} \mathrm{dm}^{-3}$ : $\mathrm{Na}, \mathrm{K}, \mathrm{Fe}, \mathrm{Al}, \mathrm{Mn}$, $\mathrm{P}, \mathrm{S}$ in $10 \%$ nitric acid (comprising HF traces) was used for the calibration of ICP-OES (e.g., Zioła-Frankowska and Frankowski 2017). In order to preserve the standard/sample conditions, the matrix match method was used.

SRP in the water was determined by the molybdate method with ascorbic acid as a reducer. Prior to the analyses, the water samples were filtered through a rinsed $0.45 \mu \mathrm{m}$ pore size filter (Macherey-Nagel, Germany).

Statistical analyses were performed using STATISTICA 12 software (StatSoft Inc., Tulsa, USA). The normality of distributions of the analysed variables and the homoscedasticity of the samples were tested with the Shapiro-Wilk and Levene tests, respectively. The mean values for $\mathrm{pH}$ were calculated on the basis of the means of logarithmically transformed $\mathrm{H}+$ activities. Different lake groups were compared using the Mann-Whitney U test (for two groups) and ANOVA with the KruskalWallis test (for more than 2 groups). Tukey's post-hoc test was used to compare the means of the variables. For all the statistics, $\mathrm{p}<0.05$ was applied as being statistically significant. Principal Components Analysis (PCA) was performed for the statistical analysis of the physico-chemical parameters data set. Prior to this analysis, the data (except $\mathrm{pH}$ values) was subject to logarithmic transformation $(\log (1+x))$ to minimize the discrepancies between the empirical distribution of the variables and their theoretical normal variation. Among the studied environmental variables, speciation forms of nutrients that were highly interrelated were reduced 
to TC, TP and TN and included in the PCA. A similar procedure was applied in the case of $\mathrm{Fe}^{3+}$ and $\mathrm{SO}_{4}{ }^{2-}$, so that only total $\mathrm{Fe}$ and $\mathrm{S}$ were considered. Additionally, to reduce the number of variables, a simple factor analysis was applied. Covariation was tested using the non-parametric Spearman Rank Correlation.

\section{Results}

\section{Physico-chemical differentiation}

All the analysed lakes differed significantly as regards their basic physico-chemical parameters. SD visibility, $\mathrm{pH}, \mathrm{EC}$, colour, hardness, TN, TC, $\mathrm{Ca}^{2+}, \mathrm{Mg}^{2+}$, $\mathrm{Fe}, \mathrm{Al}, \mathrm{Mn}, \mathrm{S}, \mathrm{TP}$ and, additionally Chl- $a$ were vari- ables significantly differentiating the physico-chemical composition of water of the analysed lakes. The PCA analysis was performed with regard to these variables (Fig. 2). The first two main components (Axis 1 and 2) explained $80 \%$ of the observed variance. The PCA output proved $\mathrm{pH}, \mathrm{EC}, \mathrm{Ca}^{2+}, \mathrm{Mg}^{2+}, \mathrm{Mn}, \mathrm{TC}, \mathrm{S}$ and total hardness (correlated with the first axis, $r>0.80$ ), as well as colour and TN (correlated with the second axis, $r>0.80$ ), to be primarily responsible for the observed variance.

Based on this output, two distinct groups of lakes were distinguished: A - lakes characterized by high visibility, low $\mathrm{pH}$, low concentrations of nutrients and Chl- $a$, and B - lakes characterized by lower water trans-

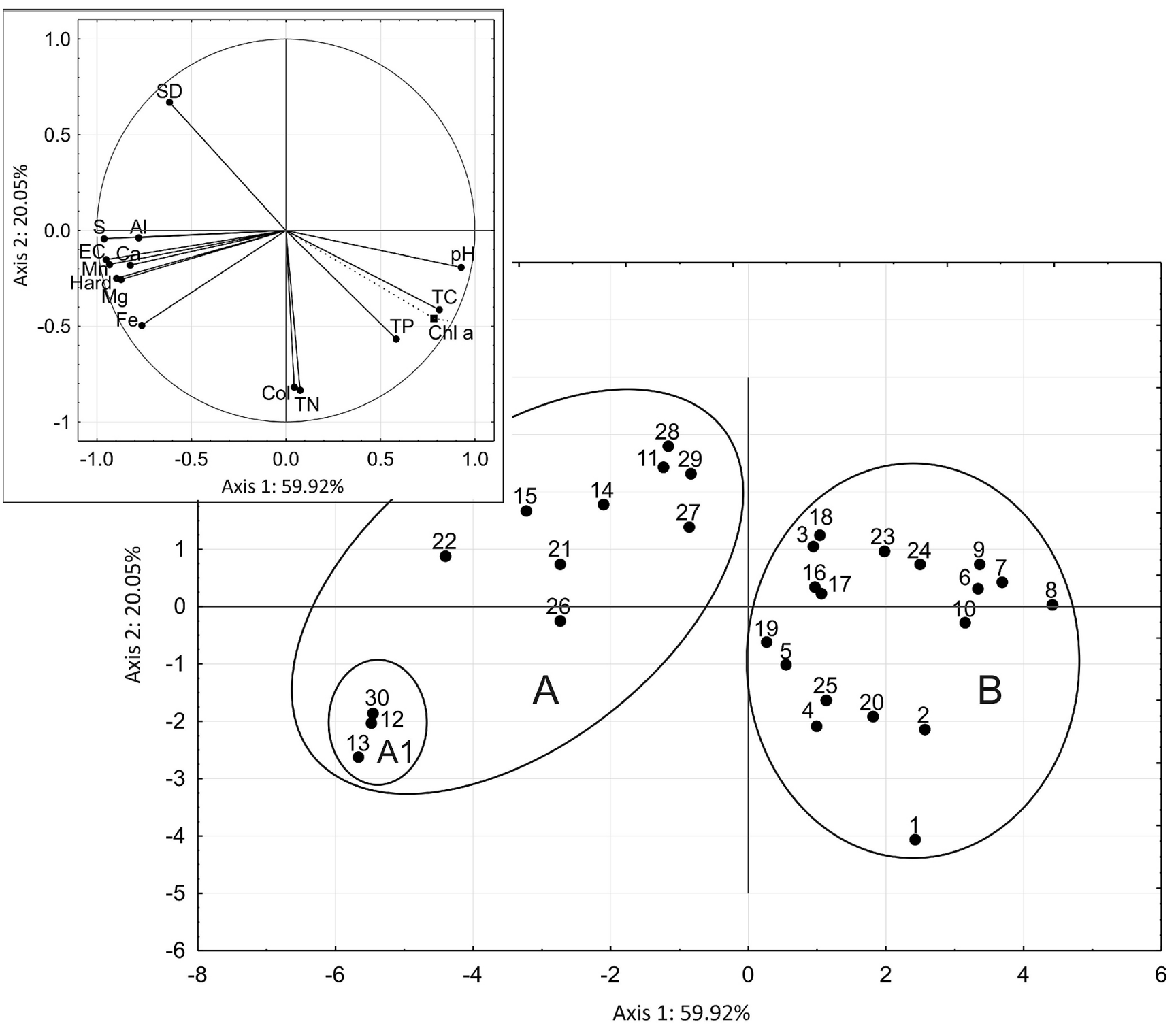

Fig. 2. The Principal Components Analysis (PCA) for the lakes studied in the Muskau Arch - differentiation across the selected hydrochemical characteristics (preceded by factor analysis). The distinguished groups of lakes are encircled and marked with capital letters 
Table 2. Physico-chemical characteristic (mean and stand. dev.) for the parameters significantly $(\mathrm{p}<0.05)$ differentiating the PCA output groups

\begin{tabular}{|l|c|c|c|c|c|}
\hline \multicolumn{1}{|c|}{ Variable } & Unit & Group A $(\mathrm{n}=9)$ & Group A1 $(\mathrm{n}=3)$ & Group B $(\mathrm{n}=18)$ & $\mathrm{K}-\mathrm{W} H$ test \\
\hline Secchi depth & {$[\mathrm{m}]$} & $4.5 \pm 1.66$ & $3.2 \pm 0.90$ & $1.5 \pm 0.59$ & $\mathrm{p}<0.0001$ \\
\hline $\mathrm{pH}$ & & $3.4 \pm 0.40$ & $2.8 \pm 0.06$ & $6.9 \pm 0.55$ & $\mathrm{p}<0.0001$ \\
\hline Conductivity & {$\left[\mathrm{\mu S} \mathrm{cm}{ }^{-1}\right]$} & $636.6 \pm 309.61$ & $1718.7 \pm 682.00$ & $222.9 \pm 95.49$ & $\mathrm{p}<0.0001$ \\
\hline Colour & {$\left[\mathrm{mg} \mathrm{Pt} \mathrm{dm}^{-3}\right]$} & $3.0 \pm 0.00$ & $35.1 \pm 17.12$ & $17.6 \pm 24.46$ & $\mathrm{p}<0.001$ \\
\hline $\mathrm{Ca}$ & {$\left[\mathrm{mg} \mathrm{dm}^{-3}\right]$} & $53.7 \pm 23.79$ & $152.63 \pm 68.69$ & $26.94 \pm 15.84$ & $\mathrm{p}<0.0001$ \\
\hline $\mathrm{Mg}$ & {$\left[\mathrm{mg} \mathrm{dm}^{-3}\right]$} & $11.9 \pm 5.94$ & $29.0 \pm 10.71$ & $5.4 \pm 3.08$ & $\mathrm{p}<0.001$ \\
\hline $\mathrm{Fe}$ & {$\left[\mathrm{mg} \mathrm{dm}^{-3}\right]$} & $3.8 \pm 6.22$ & $89.4 \pm 55.68$ & $0.8 \pm 1.59$ & $\mathrm{p}<0.0001$ \\
\hline $\mathrm{Al}$ & {$\left[\mathrm{mg} \mathrm{dm}^{-3}\right]$} & $1.86 \pm 2.55$ & $7.64 \pm 7.79$ & $0.07 \pm 0.05$ & $\mathrm{p}<0.0001$ \\
\hline $\mathrm{Mn}$ & {$\left[\mathrm{mg} \mathrm{dm}^{-3}\right]$} & $0.96 \pm 0.46$ & $2.78 \pm 0.29$ & $0.21 \pm 0.16$ & $\mathrm{p}<0.0001$ \\
\hline $\mathrm{TC}$ & {$\left[\mathrm{mg} \mathrm{dm}^{-3}\right]$} & $1.56 \pm 0.85$ & $1.84 \pm 0.94$ & $19.43 \pm 9.17$ & $\mathrm{p}<0.0001$ \\
\hline $\mathrm{TN}$ & {$\left[\mathrm{mg} \mathrm{dm}^{-3}\right]$} & $0.47 \pm 0.30$ & $1.79 \pm 0.08$ & $1.12 \pm 0.63$ & $\mathrm{p}<0.001$ \\
\hline TP & {$\left[\mathrm{mg} \mathrm{dm}^{-3}\right]$} & $0.014 \pm 0.020$ & $0.007 \pm 0.006$ & $0.077 \pm 0.053$ & $\mathrm{p}<0.001$ \\
\hline $\mathrm{S}$ & {$\left[\mathrm{mg} \mathrm{dm}^{-3}\right]$} & $78.3 \pm 41.50$ & $317.33 \pm 36.12$ & $16.16 \pm 14.67$ & $\mathrm{p}<0.0001$ \\
\hline Hardness & {$\left[{ }^{\circ} \mathrm{dH}^{-3}\right.$} & $10.30 \pm 4.68$ & $28.12 \pm 12.06$ & $5.16 \pm 2.68$ & $\mathrm{p}<0.001$ \\
\hline Chlorophyll-a & {$\left[\mathrm{g} \mathrm{dm}^{-3}\right]$} & $1.45 \pm 1.02$ & $1.10 \pm 0.67$ & $9.46 \pm 6.81$ & $\mathrm{p}<0.0001$ \\
\hline
\end{tabular}

parency, higher $\mathrm{pH}$, and higher nutrient concentrations. It should also be noted that both groups (with a slightly greater diversity in group B) were very varied in terms of water colour, which was also in line with TN concentration.

Within the first group of lakes (A), a smaller cluster (A1) of three lakes was distinguished. These lakes were characterized by significantly higher water mineralization and concentration of $\mathrm{S}, \mathrm{Fe}, \mathrm{Ca}^{2+}, \mathrm{Mg}^{2+}$ and $\mathrm{Mn}$ ions (Table 2). It is noticeable that the obtained groups of lakes differed significantly in terms of age. Lakes within group B were the oldest (104 years on average), whereas those in group A and A1 were the youngest (62 and 47 years on average, respectively). No differences in the morphometric features (max depth and area) were found.

\section{Origin}

The comparison of the lakes in terms of their origin (extracted material) showed little diversification between the lakes. Significant differences $(\mathrm{p}<0.05)$ between coal and lime lakes were found only for four parameters: colour, TOC, $\mathrm{TN}$ and $\mathrm{N}_{\mathrm{ORG}}$. For all these parameters, the highest values were found in coal pit lakes and the lowest, in lime ones.

Much greater diversity was observed in lake genesis (the method of extraction). 15 out of 28 analysed parameters significantly differentiated between the studied lakes: $\mathrm{pH}, \mathrm{EC}, \mathrm{S}, \mathrm{SD}$ visibility, TC, TOC, TP, Al, $\mathrm{Ca}$, Chl- $a$, hardness, $\mathrm{Mn}, \mathrm{Na}, \mathrm{NH}_{4}$, and $\mathrm{N}_{\text {org }}$ (Fig. 3). Open-cut lakes had the lowest $\mathrm{pH}$ (3.9 on average) and highest water mineralization ( $853 \mu \mathrm{S} \mathrm{cm} \mathrm{cm}^{-1}$ on average). Those lakes were also characterized by low nutrient concentrations $\left(7.93,0.87\right.$ and $0.022 \mathrm{mg} \mathrm{dm}^{-3}$ on average for TC, TN and TP, respectively) and high water transparency ( $3.5 \mathrm{~m}$ on average).
Sink hole lakes had the highest values of $\mathrm{pH}$ and the lowest values of conductivity. These lakes had clearly higher trophy (including Chl- $a 9.0 \mathrm{mg} \mathrm{dm}^{-3}$ on average), which was also reflected in low water transparency (1.7 $\mathrm{m}$ on average). Intermediate values were observed in sink hole/open-cut lakes.

Different methods of extraction, and hence of lake formation, did not have a significant influence ( $p$ $>0.05$ ) on the diversification of morphometric structure (depth, surface area).

The lakes differed significantly in terms of age $(\mathrm{p}$ $<0.05)$ : sink hole lakes were the oldest and open-cut lakes - the youngest.

\section{Age}

The correlation analyses showed that half (14) of the analysed physico-chemical parameters were significantly correlated with the lakes' age (Fig. 4). Positive correlations were found for $\mathrm{pH}, \mathrm{Cl}$, TC, TOC, $\mathrm{N}_{\mathrm{ORG}}$, TP, and Chl- $a$ concentrations. The other parameters (SD visibility, $\mathrm{EC}, \mathrm{SO}_{4}^{2-}, \mathrm{Al}, \mathrm{Mn}, \mathrm{NH}_{4}^{+}, \mathrm{S}$ ) were negatively correlated with the ages of the lakes'. Correlation analysis showed that $\mathrm{pH}$ increasing with age was accompanied by a decrease in water mineralization, which was not only indicated by the negative correlation with conductivity, but also by the decreasing content of sulfates, $\mathrm{NH}_{4}^{+}, \mathrm{Mn}$ or Al. In addition, as the lakes get older, nutrient (TC, TP, $\mathrm{N}_{\mathrm{ORG}}$ ) concentrations grow, accompanied by increasing chlorophyll- $a$ concentration and decreasing visibility.

\section{Discussion}

The study showed that mining lakes of the Muskau Arch are very diverse in terms of habitat conditions, both regarding morphological structure and water 


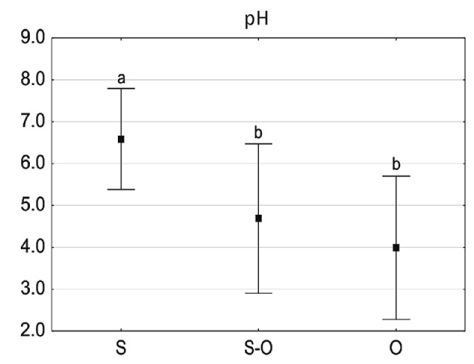

$\mathrm{KW}-\mathrm{H}(2 ; 30)=9.7406 ; \mathrm{p}=0.0077$

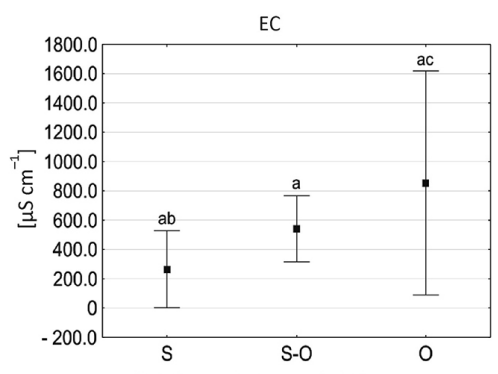

$\mathrm{KW}-\mathrm{H}(2 ; 30)=12.0023 ; \mathrm{p}=0.0025$

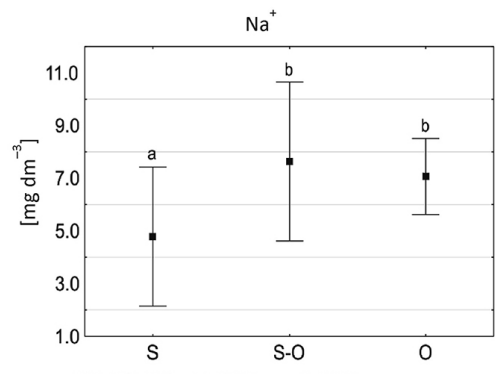

$\mathrm{KW}-\mathrm{H}(2 ; 30)=7.6152 ; \mathrm{p}=0.0222$

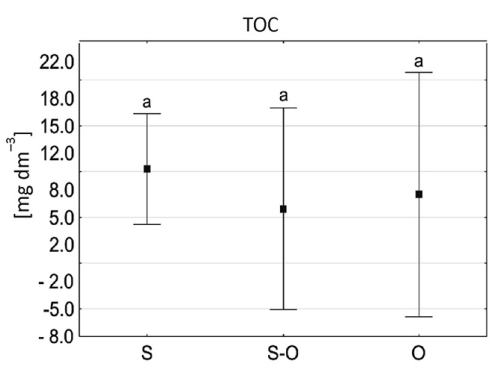

$\mathrm{KW}-\mathrm{H}(2 ; 30)=6.9798 ; \mathrm{p}=0.0305$

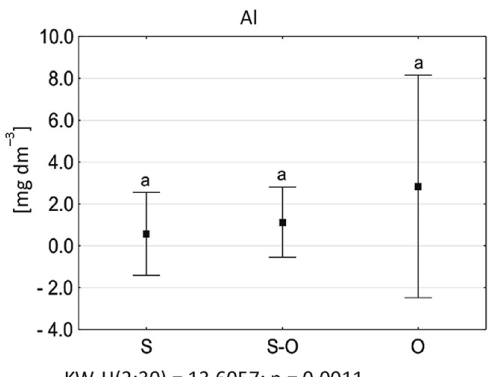

Secchi depth

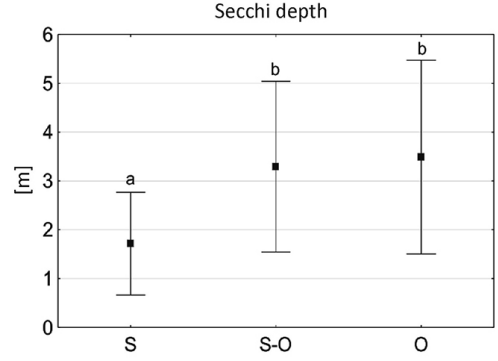

$\mathrm{KW}-\mathrm{H}(2 ; 30)=7.3299 ; \mathrm{p}=0.0256$

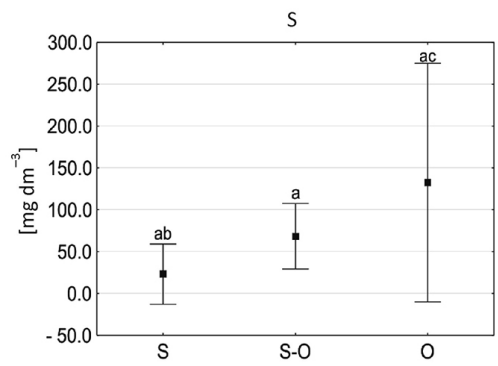

$\mathrm{KW}-\mathrm{H}(2 ; 30)=10.8737 ; \mathrm{p}=0.0044$

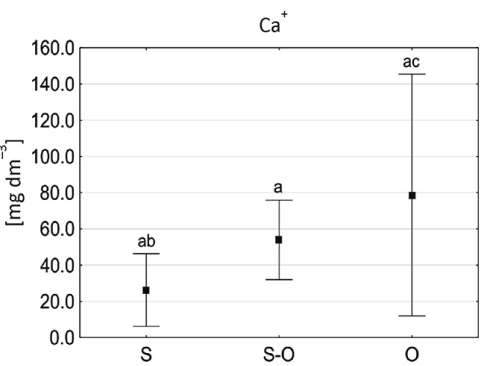

$\mathrm{KW}-\mathrm{H}(2 ; 30)=9.2963 ; \mathrm{p}=0.0096$

TC

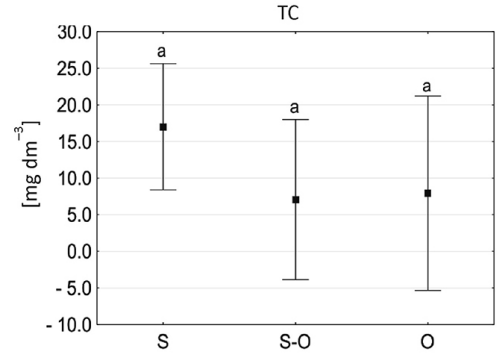

$\mathrm{KW}-\mathrm{H}(2 ; 30)=8.1290 ; \mathrm{p}=0.0172$

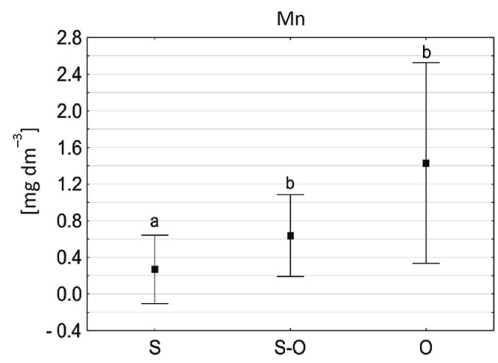

$\mathrm{KW}-\mathrm{H}(2 ; 30)=12.8044 ; \mathrm{p}=0.0017$

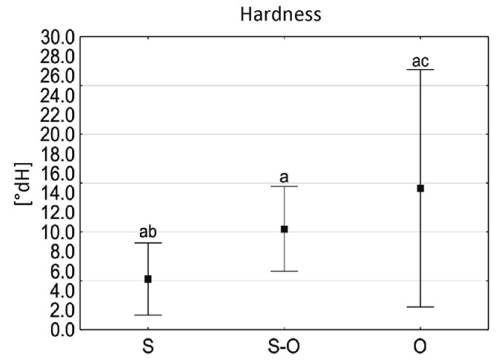

$K W-H(2 ; 30)=8.0733 ; p=0.0177$

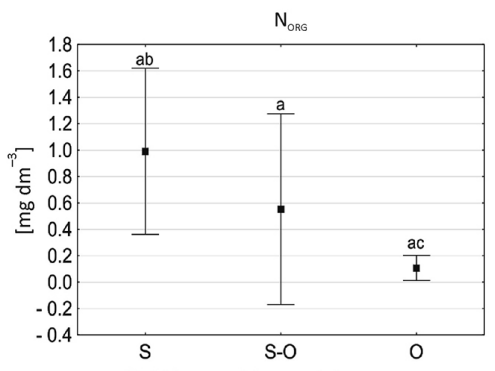

$K W-H(2 ; 30)=13.6367 ; p=0.0011$

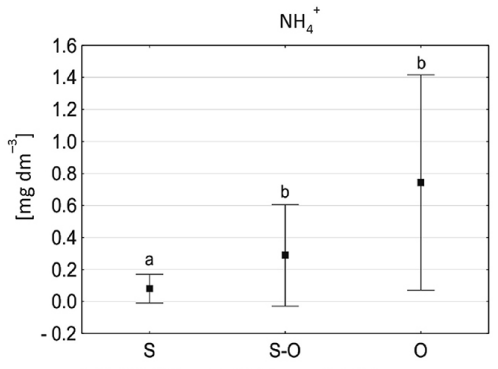

$K W-H(2 ; 30)=11.6287 ; p=0.0030$

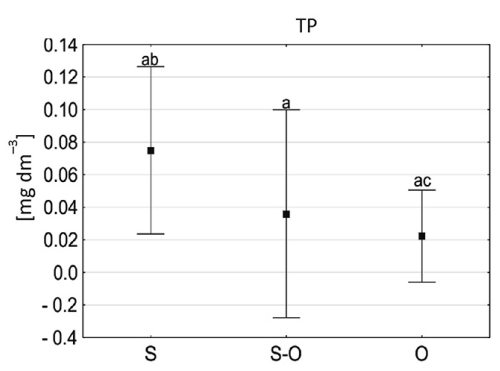

$K W-H(2 ; 30)=9.9032 ; p=0.0071$

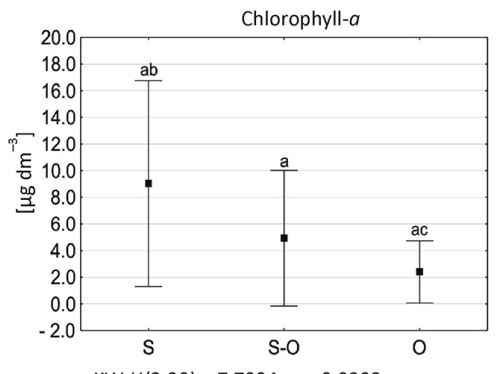

$\mathrm{KW}-\mathrm{H}(2 ; 30)=7.7994 ; \mathrm{p}=0.0202$

Fig. 3. Physico-chemical parameters significantly differentiating the lakes against the background of the lake origin. Mid points and bars are the means \pm SD. Different letters above the bars indicate significant $(\mathrm{p}<0.05)$ differences between the distinguished groups of lakes Abbreviations: $S$ - sink hole $(n=15), O$ - open-cut $(n=6), S / O-\operatorname{sink}$ hole/open-cut $(n=9)$. 

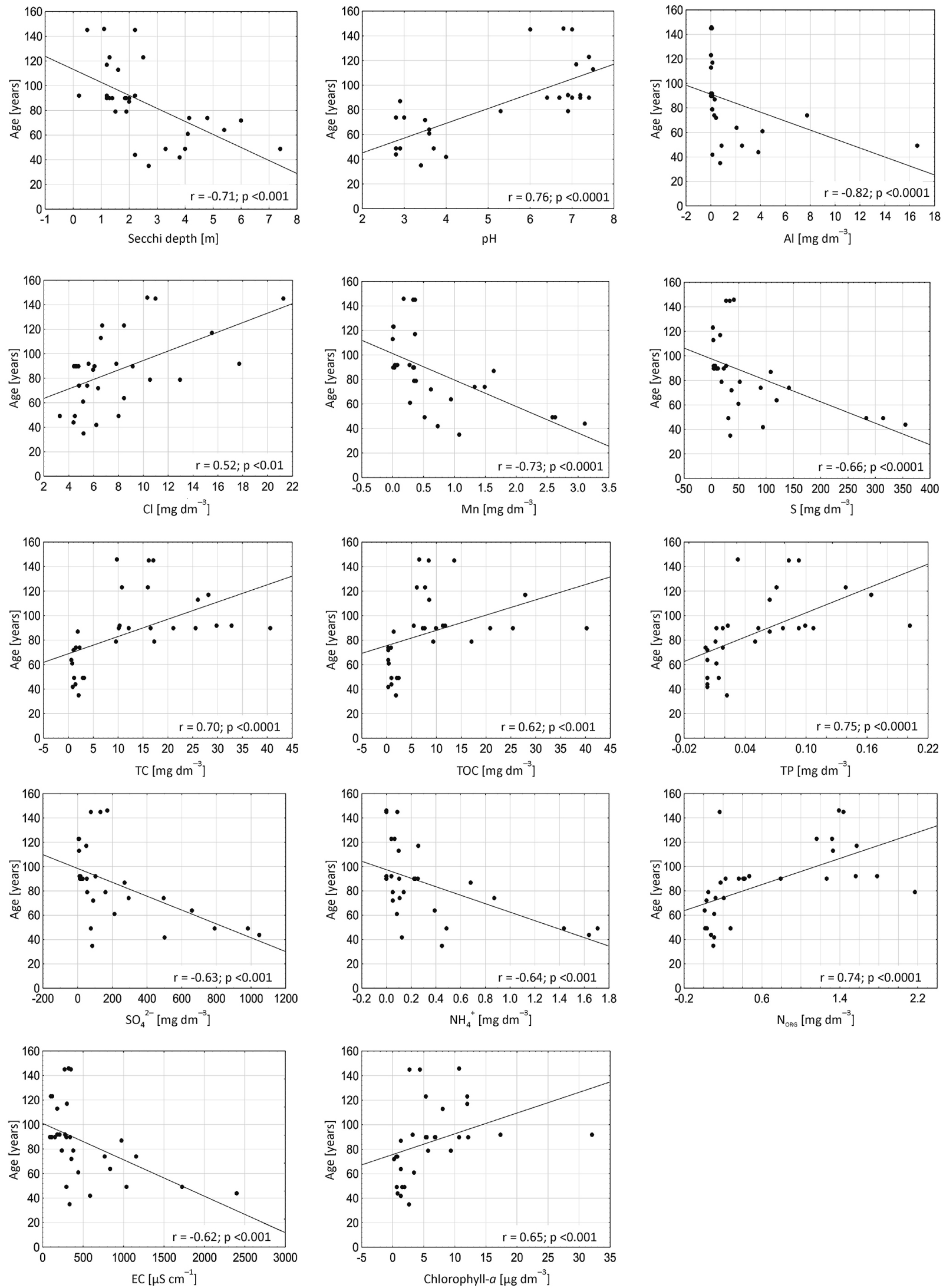

Fig. 4. Correlation graphs for the physico-chemical parameters significantly $(\mathrm{p}<0.05)$ correlated with the age of the lakes $(\mathrm{n}=30)$ 
chemistry. It is reflected i.a., in the water colour (from transparent light blue and turquoise, through green and yellow, up to orange and red), which was one of the parameters that significantly differentiated between the lakes. This is the reason why the area is commonly known as the colourful lake district. In surface waters, colour is mostly determined by the presence of humic substances and other products of organic matter decomposition (Dojlido and Best 1993). The fact that higher colour values were found in waters with higher trophy (high values of Chl- $a$ and nutrients) also seems to confirm this relation with regard to the investigated lakes. For the same reason, in lakes with the lowest nutrient concentration, colour values were the lowest. Additionally, this relation was also expressed to some extent in the PCA output, where colour was strongly positively correlated with $\mathrm{TN}$, whose highest fraction is organic nitrogen $\left(\mathrm{N}_{\mathrm{ORG}}\right)$.

On the other hand, in most coal lakes, varied water colour (not always reflected in high values obtained in the applied method) mainly results from the chemical composition of minerals of the mines in which the lakes were formed (including dissolved compounds of sulfur, silicon and iron) (Skoczyńska-Gajda and Labus 2011). This is as a result of so-called Acid Mine Drainage (AMD), causing the washing out and oxidation of the surrounding rock, e.g., pyrite, leading to increased acidity (Lutyńska and Labus 2015). The findings clearly show that the $\mathrm{pH}$ of water is one of the key factors influencing the chemical diversity of lakes in the Muskau Arch. This is confirmed by the clear distinction of A1 lakes in the PCA, whose waters had both the highest mineralization and acidity, resulting in the typical reddish-brown colour of water and relatively low visibility (Boehrer 2013). It definitely results from a similar origin of the lakes (they were formed in open-cut coal extraction pits) and their young age (44-49 years). In addition, it is likely all three of them are fed with water from the same auriferous layer, as suggested by their proximity and landform features of the drainage area.

It is worth noting that some lakes with very low $\mathrm{pH}$ had very high visibility and turquoise-blue colour (lakes no. 11, 14, 27, 28, 29). Their different character may be connected with a somewhat different origin, since in all of them clay was extracted with the opencut method apart from coal. Currently, considerable deposits of clay and fine grain sand make the basins of these lakes. As suggested by Mostofa et al. (2013), fine quartz fractions and silicon compounds washed out by ground water may be the reason for the characteristic colour. This effect is reinforced by the high transparency of water, as a result of which the light penetrates deeply and is reflected from the bottom. In such a case, the observer can see a truncated radiation spectrum, with the advantage of shorter wavelengths - blue and violet (Wetzel 2001).

The colour and high water visibility are definitely the result of extremely low nutrient concentrations, preventing the development of phytoplankton (Marszelewski et al. 2017). It is also one of the factors that slow down the neutralization of water in the lakes, and thus, their further evolution (Nixdorf et al. 2010). Apart from $\mathrm{pH}$ and mineralization, changing trophy (nutrients and Chl- $a$ concentrations) was the reason for the lake diversity. It was also significant for the higher colour values and low water transparency in group B identified in the PCA output. The highest $\mathrm{pH}$ values were also found in these lakes, pointing to the progressing neutralization of water. Visibly higher macrophyte diversity observed in the lakes during the study also confirms this. The process is certainly connected to a great extent with the natural evolution of mining lakes (Sienkiewicz and Gąsiorowski 2016). In most cases, the inflow of precipitation and ground waters leads to the dilution of acidic water (Schultze et al. 2002), which enables a gradual settling of plankton organisms (a pioneer group). The process is relatively slow, which is confirmed by very low $\mathrm{pH}(<3.0)$ in several lakes aged over 70 or even 80 years. This is in line with studies carried out by other authors (Sienkiewicz and Gąsiorowski 2016). On the other hand, there were also lakes where the $\mathrm{pH}$ was close to neutral despite their relatively young age. This is the effect of water neutralization, which was carried out in order to stock the lakes with fish. Such activities are implemented in many countries intentionally as a method of recultivation of pit lakes (Nixdorf et al. 2010). In the case of mining lakes, calcium hydroxide is most commonly used. Besides, so as to speed up biological production, biological neutralization is sometimes applied (Wendt-Potthoff et al. 2002). Upon exceeding pH 4.5 (as stated in most of the investigated lakes), the neutralization process is very quick and hard to reverse (Brugam and Lusk 1986). It is estimated that neutralization has been used in at least 15 of the investigated lakes (no official data). Due to the lack of applicable legal regulations, these activities were usually not carefully designed (calcium oxide and domestic waste water were often used), which in some cases led to degradation (eutrophication). The presented findings also confirm this. Currently, they are all used for fishing purposes, being the property of private leaseholders or the Polish Angling Association.

In natural lakes, one of the important factors which can create a variety of water physico-chemical parameters (and as a result, diverse habitat conditions) is morphometric structure (Wetzel 2001). In the case of the investigated pit lakes, morphometric features (surface area and maximum depth) were irrelevant. Interest- 
ingly, no significant differences were found between pit lakes from open-cut mines and lakes in sink holes. In our opinion, this may result from the fact that in both groups of lakes the morphometry was determined by the size and vertical range of the deposit. Still, the presented findings confirmed the hypothesis that one of the significant factors causing the variety of mining lakes is their origin. First, it may have been affected by the time of filling the lake with water, which is longer in the case of sink holes (Lessmann et al. 2003). Additionally, before sink holes start to fill up with water, organic matter is accumulated there. After mineralization, this provides the supply of nutrients for water autotrophs (Wendt-Potthoff et al. 2002). For this reason, lakes in sink holes generally had higher trophy and poorer water quality. Second, in the case of open-cut pits, mineral layers are directly disturbed, and thus, mineral fractions are directly washed out (eroded) by water. Aquifers are also much more disturbed there (Friese et al. 2013).

The fact that half the parameters were significantly (or even strongly) correlated with the lakes' age confirms the hypothesis that the aging of lakes is the key factor causing their diversification. Apart from natural processes of changing the physico-chemical parameters of water that result from natural aging involving water neutralization and biological succession (Sienkiewicz and Gąsiorowski 2016), human impact is also crucial. The proof for this may be the observation that the lakes with the poorest water quality (e.g., no. 1, 2, 10 and 25) were not the oldest ones. In these lakes, the highest values of chlorophyll a and nutrient concentrations were observed, which is in agreement with the fact that they were subject to the process of liming and fertilization with domestic waste water. Thus, the natural evolution process was in a way accelerated. On the one hand, it may be assumed that this promotes greater diversity. On the other hand, it clearly has a negative impact on natural processes and water quality. In our opinion, it is necessary to take action (e.g., prohibit forced neutralization and fish stocking) to protect these unique ecosystems and their "natural" character.

\section{Conclusions}

The mining lakes of the Muskau Arch are very diverse in terms of water chemistry, thereby promoting a diversity of habitat conditions. Despite a great diversity of morphometric structure, it was not a significant factor for water chemistry. The varied water colour, which is a characteristic feature of the investigated lakes, reflected the physico-chemical differentiation of water to a great extent. In contrast to the origin, the genesis and age of the lakes were factors that significantly influenced their diversity.
Apart from natural processes altering the physicochemical parameters of water, human impact (neutralization and fertilization carried out in order to fish stock) is also crucial for accelerating the natural evolution of the lakes. However, in our opinion the obtained results must be considered carefully since the data was gathered in-situ and for one season only, thus many other factors could affect the differentiation of lakes. Therefore, a detailed study including a wider set of parameters (including phytoplankton, macrophytes and zooplankton structure), and analysis of vertical variability of water properties seems to be desirable. This will be considered in our further study.

\section{Acknowledgements}

We thank Mr Jacek Koźma from the Polish Geological Institute National Research Institute for all the provided information and assistance in the interpretation of the collected data.

\section{References}

Baird R., Bridgewater L., 2017, Standard methods for the examination of water and wastewater, American Public Health Association, Washington.

Blanchette M.L., Lund M.A., 2016, Pit lakes are a global legacy of mining: an integrated approach to achieving sustainable ecosystems and value for communities, Curr. Opin. Environ. Sustainability 23: 28-34.

Boehrer B., 2013, Physical properties of acidic pit lakes, [in:] Geller W, Schultze M, Kleinmann R, Wolkersdorfer C. (eds), Acidic pit lakes, Springer, Berlin-Heidelberg: 2342.

Brugam R.B., Lusk M., 1986, Diatom evidence for neutralization in acid surface mine lakes, [in:] Smol J.P., Battarbee R.W., Davis R.B, Meriläinen J. (eds), Diatoms and lake acidity, Dr W. Junk Publishers, Dordrecht: 115-129.

Dawczyk G., Maciantowicz M., 2014, Dawne górnictwo i kolejnictwo na terenie Łuku Mużakowa - Aus der Geschichte des Bergbaus Und der Bahn im Muskauer Faltenbogen (Former mining and railway in the area of the Muskau Arch), Wydaw. Drukarnia Chroma, Żary, 90 pp (in Polish, English summary).

Dojlido J., Best G.A., 1993, Chemistry of water and water pollution, E. Horwood Ltd., New York, 363 pp.

Friese K., Herzsprung P., Schultze M., 2013, Limnochemistry of water and sediments of acidic pit lakes, [in:] Geller W, Schultze M, Kleinmann R, Wolkersdorfer C. (eds), Acidic pit lakes, Springer-Verlag, Berlin-Heidelberg: 42-75.

Golterman H.L, 1969, Methods for chemical analysis of fresh waters, Blackwell Scientific, Oxford-Edinburgh, 172 pp.

Jędrczak A., 1992, Skład chemiczny wód pojezierza antropogenicznego w Łuku Mużakowskim (Chemical composition of the waters of the anthropogenic lakeland in the 
Muskau Arch), Wydaw. WSI Ziel. Góra, Zielona Góra, $132 \mathrm{pp}$ (in Polish, English summary).

Jędrczak A., Jachimko B., Najbar B., 1998, Zmiany fizycznochemicznych cech wód największego zbiornika meromiktycznego na pojezierzu antropogenicznym w okresie kilkunastu lat (Changes in the physico-chemical properties of water in the largest meromictic pit lakes in the anthropogenic lakeland over a dozen years), Zesz. Nauk. PZ - Inż. Środ. 116: 5-17 (in Polish, English summary).

Kasztelewicz Z., 2012, Blaski i cienie górnictwa wêglowego w Polsce (Pros and cons of coal mining in Poland), Polityka Energetyczna 15(4): 7-27 (in Polish, English summary).

Koschorreck M., Tittel J., 2002, Benthic photosynthesis in an acidic mining lake (pH 2.6), Limnol. Oceanogr. 47(4): 1197-1201.

Koźma J., 2016, Antropogeniczne zmiany krajobrazu związane $\mathrm{z}$ dawnym górnictwem węgla brunatnego na przykładzie polskiej części obszaru łuku Mużakowa (Anthropogenic landscape changes connected with the old brown coalmining based on the example of the Polish part of the Muskau Arch area), Gór. Odkryw. 57(4): 5-13 (in Polish, English summary).

Koźma J., Kupetz M., 2008, The transboundary Geopark Muskau Arch, Prz. Geol. 56(8/1): 692-698.

Kupetz M., 1997, Geologischer bau und genese der Stauchendmoräne Muskauer Faltenbogen (Geological structure and genesis oft he Muskau push moraine) Brandenburg. Geowiss. Beitr. 4(2): 1-20 (in German).

Lutyńska S., Labus L., 2015, Identification of processes controlling chemical composition of pit lakes waters located in the eastern part of Muskau Arch (Polish-German borderland), Arch. Environ. Prot. 41(3): 60-69.

Lessmann D., Uhlmann W.,Gruyoungald U., Nixdorf B., 2003, Sustainability of the flooding of brown coal mining lakes as a remediation technique against acidification in the Lusatian mining district, Germany, [in:] Proceedings of the 6th International Conference on Acid Rock Drainage (ICARD), 14-17 July 2003, Cairns (Australia): 521-527.

Marszelewski W., Dembowska E.A., Napiórkowski P., Solarczyk A., 2017, Understanding abiotic and biotic conditions in post-mining pit lakes for efficient management: A case study (Poland), Mine Water Environ. 36(3): 418-428.

Matejczuk W., 1986, Charakterystyka ekologiczna zbiorników wodnych $\mathrm{w}$ wyrobiskach poeksploatacyjnych węgla brunatnego (Ecological characteristic of pit lakes in the coal mining excavations) [PhD Thesis], Politechnika Wrocławska, Instyt. Inż. Ochr. Środ., Wrocław, 122 pp (in Polish, English summary).

Matejczuk W., 1989, Plankton poeksploatacyjnych zbiorników wodnych $\mathrm{z}$ rejonu Trzebiela (Plankton of the pit lakes in the mining excavations in Trzebiel area), [in:] Radkiewicz J. (ed.), Przyroda Środkowego Nadodrza, Wydaw. WSP Ziel. Góra, Zielona Góra: 93-118 (in Polish, English summary).
Moser M., Weisse T., 2011, The most acidified Austrian lake in comparison to a neutralized mining lake, Limnologica 41(4): 303-315.

Mostofa K.M.G., Yoshioka T.,Mottaleb A., Vione D., 2013, Photobiogeochemistry of organic matter: Principles and practices in water environments, Springer, Berlin-Heidelberg, 917 pp.

Najbar B., Jędrczak A., 1998, Stopień zeutrofizowania wód zbiorników pojezierza antropogenicznego (The scale of water eutrophication in the reservoirs of the anthropogenic lakeland), Zesz. Nauk. PZ - Inż. Środ. 116: 19-37 (in Polish, English summary).

Nixdorf B., Wollmann K., Deneke R., 1998, Ecological potentials for planktonic development and food web interactions in extremely acidic mining lakes in Lusatia, [in:] Geller W., Klapper H., Salomons W. (eds), Acidic mining lakes, Springer, Berlin-Heidelberg: 147-167.

Nixdorf B., Uhlmann W., Lessmann D., 2010, Potential for remediation of acidic mining lakes evaluated by hydrogeochemical modelling: Case study Grünewalder Lauch (Plessa 117, Lusatia/Germany), Limnologica 40: 167-174.

Rzymski P., Klimaszyk P., Marszelewski W., Borowiak D., Mleczek M., Nowiński K., Pius B., Niedzielski P., Poniedziałek B., 2017, The chemistry and toxicity of discharge waters from copper mine tailing impoundment in the valley of the Apuseni Mountains in Romania, Environ. Sci. Pollut. Res. 24(26): 21445-21458.

Samecka-Cymerman A., Kempers A.J., 2004, Toxic metals in aquatic plants surviving in surface water polluted by copper mining industry, Ecotoxicol. Environ. Saf. 59(1): 64-69.

Schultze M., Boehrer B., Kuehn B., Büttner O., 2002, Neutralisation of acidic mining lakes with river water, Verh. Int.Verein. Limnol. 28: 936-939.

Schultze M., Boehrer B., 2008, Development of two meromictic pit lakes - a case study from the former brown coal mine Merseburg-Ost, Germany, [in:] Proc. of the 10th IMWA Congress: Mine Water and the Environment, 2-5 June 2008, Karlovy Vary: 611-614.

Schultze M., Pokrandt K-H., Hille W., 2010, Pit lakes of the Central German brown coal mining district: Creation, morphometry and water quality aspects, Limnologica 40(2): 148-155.

Schultze M., Boehrer B., Geller W., 2013, Morphology, Age and Development of Pit lakes, [in:] Geller W., Schultze M., Kleinmann R., Wolkersdorfer C. (eds), Acidic pit lakes, Springer, Berlin-Heidelberg: 265-291.

Sienkiewicz E., Gąsiorowiski M., 2016, The evolution of a mining lake - From acidity to natural neutralization, Sci. Total Environ. 557-558: 343-353.

Skoczyńska-Gajda S., Labus M., 2011, Metal speciation in river bed sediments within the Polish part of Muskau Arch Geopark, Arch. Env. Protect. 37(3): 87-92.

Wendt-Potthoff K., Frommichen R., Herzsprung P., Koschorreck M., 2002, Microbial Fe(III) reduction in acidic min- 
ing lake sediments after addition of an organic substrate and lime, Water Air Soil Pollut. Focus 2(3): 81-96.

Wetzel R.G., 2001, Limnology: Lake and river ecosystems, Academic Press, San Diego, 1006 pp.
Zioła-Frankowska A., Frankowski M., 2017, Determination of selected metals in wines using inductively coupled plasma optical emission spectrometry with mini torch, Food Anal. Methods 10(1): 180-190. 